Nicky Rousseau

University of the Western Cape

\title{
Speak Out on Poverty: Hearing, Inaudibility, and Citizenship in Post-Apartheid South Africa
}

In 1998, Speak Out on Poverty held hearings across South Africa shortly after the Truth and Reconciliation Commission (TRC) completed eighteen months of highly publicized, nationwide hearings at which victims testified. Speak Out challenged the TRC's focus on overt political violations, seen to occlude forms of structural violence central to apartheid's policy and practice, as well as longer legacies of colonialism. Reading Speak Out alongside the TRC puts pressure on supposed differences between official truth commissions or tribunals and those run by civil society. Discussing Speak Out in relation to the TRC signaled more than a set of comparisons. In a time of transition, Speak Out spoke from within and against the noise of the TRC. It aimed to make poverty and inequality the nation's priority rather than reconciliation, or at least to challenge notions of reconciliation that did not have inequity and poverty at its center. This intention failed to come to fruition, and Speak Out seemed paradoxically inaudible in public debate. In exploring this conundrum, this article considers particular strategic and organizational choices by Speak Out. These shaped the discursive terrain of operations and subjectivities in ways that unintentionally enabled inaudibility and constrained the organizers' transformative intentions. [People's tribunals, South African Truth and Reconciliation Commission, structural violence, Speak Out on Poverty, testimony]

In 1998, after some fifteen months of highly publicized victim hearings convened by South Africa's Truth and Reconciliation Commission (TRC), public hearings dubbed Speak Out on Poverty (hereafter Speak Out) took place. A coalition of nongovernmental organizations (NGOs), together with rights institutions established by the first post-apartheid parliament, organized the hearings. Speak Out hearings convened in urban and rural areas across South Africa and spoke to what is seen as a "blind spot" in the TRC's mandate: its focus on overt political violations. Critics saw this focus as occluding forms of structural violence, which were central to apartheid's policy and practice, and colonialism's longer legacies.

With political negotiations center stage in the early 1990s, behind-the-scenes local and international businesses brought much persuasion and pressure to bear on the post-apartheid economy (Terreblanche 2012). Further, negotiations coincided with the end of the Cold War and an ascendant neoliberal global order, narrowing South Africa's economic options. Thus, while negotiations decisively ended white minority rule, these negotiations were less successful in addressing effects of colonial and apartheid rule, notably poverty and inequality. Indeed, in 1993, a Gini coefficient of 0.593 located South Africa among the most inequitable countries in the world. ${ }^{1}$ In 1994, the year of the first democratic elections, South Africa's Human Development Index (HDI) score was 0.699 (United Nations Development Programme 1994, 94). Disaggregated by race, the HDI fell to 0.462 for black South Africans, while that of white South Africans rose to 0.878. In other words, while the latter were catapulted into countries classified as high-ranking, black South Africans 
plummeted to low-ranking countries. Indeed, the United Nations Development Programme (98) commented: "Not just two different peoples, these are almost two different worlds."

Speak Out aimed to place these enduring forms of poverty and inequality center stage. Also of considerable concern was the government's new macro-economic framework, dubbed Growth Employment and Redistribution (GEAR). Following a dramatic currency collapse and capital outflow, the South African government chose to implement its own "home-grown structural adjustment programme" (Bond 2003, ix) rather than accept one imposed by the World Bank and International Monetary Fund. Notwithstanding the government's insistence on its sovereign right to determine policy, and despite "pro-poor" commitments, critics saw GEAR as drawing South Africa's economy more tightly into a global neoliberal order (Bond 2003; Padayachee 1998). In response to criticism of GEAR, the government declared a "war on poverty," with then deputy president Thabo Mbeki echoing the UNDP's characterization of South Africa as two worlds. The War on Poverty Forum, established in 1997, included representatives from government, NGOs, the UNDP, trade unions, and faith organizations (The Star 1997, 7). Around this time, Mbeki characterized South Africa as "a country of two nations" in which "[one] of these nations is white, relatively prosperous, regardless of gender or geographic dispersal.... The second and larger nation of South Africa is black and poor, with the worst affected being women in the rural areas, the black rural population in general and the disabled."2

If, in 1998, this provided a context for Speak Out, it is worth noting that South Africa's poverty levels have barely shrunk, while its inequality index has grown to 0.63 , making South Africa in 2018 the most unequal society in the world (World Bank 2018). Similarly, adjusted for inequality, South Africa's HDI at 0.467 is almost identical to black South Africans in 1994. This is despite massive investment in basic social needs (electrification, sanitation, access to water and housing); a shift in economic policy from early to mid2000s toward a development state; an extensive social grant program; and increasing public protests at the slow pace of achieving a "better life for all," as promised in successive elections. The shift to a development state arose from evidence that while GEAR had succeeded in its fiscal policy, its projected growth rate had failed to materialize and there had been significant job losses.

Yet the more than six hundred testimonies and estimated participation of ten thousand people involved in Speak Out seemed unheard. Speak Out received little public attention beyond its own constituencies. Today, it is forgotten even by transitional and social justice scholars and practitioners. A smaller scale initiative in 2008 produced a few articles in various newspapers before similarly sinking into oblivion.

One track of this article seeks to revisit Speak Out as a way of engaging the paradox of its inaudibility. This is underscored by the extent, intractability, and deepening of poverty and inequality, which has been accompanied by growing political dissatisfaction and mobilization. In seeking to understand the paradox of Speak Out's inaudibility, one line of explanation is that poverty is normatively blamed on the poor rather than on the violence of structural and systemic inequality and racism. Another explanation is located in South Africa's compromised transition. However, this article is more concerned with particular strategic and organizational choices that shaped the discursive terrain of Speak Out's operations and the subjectivities that emerged. Attending to these helps to locate the ways in which practices of social or political critique - which I take Speak Out to have undertaken — can sometimes be constrained by the very conditions they seek to critique.

A second track in this article concerns distinctions drawn between truth commissions and other initiatives designed to address impunity. While South Africa's TRC is often regarded as the poster child for truth commissions, organizers did not constitute Speak Out 
as a commission. In several respects, it resembles a different strand of human rights interventions; namely, people's tribunals. People's tribunals seldom feature in the transitional justice literature, despite significant attention on other tribunals, such as the UN-sponsored International Criminal Tribunal for Yugoslavia and International Criminal Tribunal for Rwanda. A revealing rationale for this discrepancy is the different temporalities in which they operate. Truth commissions and criminal tribunals are associated with the aftermaths of violence or political transitions; conversely, people's tribunals draw attention to forms of violence that enjoy impunity and often occur in the absence of a transition. Further, while truth commissions are almost always state or internationally mandated initiatives, civil society movements drive people's tribunals (Klinghoffer and Klinghoffer 2002, 6). Relatedly, people's tribunals generally align themselves with more radical politics, and do not invoke the same degree of criticism from radicals as truth commissions tend to (Grandin and Klubock 2007; Laplante 2008; Neocosmos 2011). Thus, if truth commissions and international criminal tribunals are said to effect a break from the past and to promote legitimacy for new governments, people's tribunals seek to denounce injustices and human rights abuse, and aim to politicize and mobilize local and international support. As Edmund Jouve suggests, they also perform "grassroots justice" (quoted in Cournil and Prete, this issue).

These distinctions, although useful in some respects, are too hard and fast. If the "red thread" 3 binding people's tribunals is the state or international community's failure to hold perpetrator states to account, other threads cross between state and non-state. For example, although constituted by the state, civil society frequently plays a key role in lobbying for and initiating truth commissions, as is evident in South Africa (Boraine and Levy 1995; Hamber, Mofokeng, and Simpson 1997). ${ }^{4}$

Like truth commissions, people's tribunals share an approach oriented toward "fact finding, victim centered testimony and "truth telling.",5 Arguably, too, if reconciliation tends to frame truth commissions, their truth-telling impetus is oriented toward ending impunity. They similarly bring public secrets to view and expose and hold perpetrators to account (Fullard and Rousseau 2008, 224), even if they lack the capacity to hold the perpetrators legally accountable. Finally, the transitional justice sector itself is increasingly concerned with enduring socio-economic and identitarian harms in transitional societies.

I read the TRC and Speak Out alongside each other in order to consider truth commissions and people's tribunals' distinctions and affinities. A few methodological points are in order. I worked for the TRC from 1996 to 2001, and subsequently have researched and taught the TRC for more than two decades. My understanding is thus both "insider knowledge" and scholarly. In contrast, my only encounter with Speak Out at the time of the hearings was a poignant op-ed article, which I read in a daily newspaper in 1998. In 2012, a research project on violence and transition returned me to Speak Out. Astonishingly, while the TRC generated a veritable industry of scholarship (Gready 2011), and multiple forms of art, literature, and music, I found little more than a small seam of media articles and a handful of scholarly references on Speak Out. It barely garners a mention in the literature on socioeconomic rights, and slips entirely through that of transitional justice. After struggling to locate sufficient institutional records, I again moved Speak Out to my research backburner, although over time I have assembled a modest archive: media articles, submissions to Speak Out, ${ }^{6}$ Speak Out's reports, and hearing transcripts and summaries. It is this archive on which this article rests.

There is a danger my own TRC experience, and its "industrial-size" literature, can overwhelm Speak Out's fragmented archive. To address this, I read Speak Out alongside literature on people's tribunals and socio-economic rights. In discussing it in relation to the 
TRC, I seek less to compare the two than to reveal challenges and paradoxes in "speaking out" on poverty at a time of transition. In an extended discussion of hearings, I show how particular strategic choices shaped the discursive register of hearings, and the subjectivities produced. These choices, I suggest, had unintended and unfortunate effects-possibly enabling inaudibility as well as constraining the transformative intentions of the organizers.

\section{Speak Out and the TRC}

The South African Non-Governmental Organisation Coalition (SANGOCO), the South African Human Rights Commission (SAHRC), and the Commission for Gender Equality (CGE) organized Speak Out. SANGOCO described itself as the "largest single umbrella body of NGOs in the Southern African region," drawing together numerous NGOs around an interest in working with the needs of marginalized poor communities and sectors. While some employed professional expertise, a significant number of affiliated NGOs had more activist- or community-based roots. A number had been politically aligned to the United Democratic Front, the largest internal antiapartheid resistance movement in the 1980s. Others had their roots in Black Consciousness, trade unions, or other liberation movements; some espoused radical politics, and others situated themselves within more liberal antiapartheid paradigms.

The SAHRC and CGE are constitutionally established bodies, accountable and regulated by Parliament. Their function, along with several other bodies (including the TRC), is to "safeguard democracy"; to this end, they are independent, and "subject only to the Constitution and the law." 8 key role of the SAHRC is to monitor the government's efforts to secure "rights ... concerning housing, health care, food, water, social security, education and the environment," which are all enshrined in the Constitution's Bill of Rights. While the CGE and the SAHRC lent legitimacy, SANGOCO and its affiliate organizations took much responsibility for collecting submissions, recruiting participants, and organizing hearings. As with SANGOCO, neither the SAHRC nor CGE are homogenous institutions, but represent a range of political positionalities. Again, this is not dissimilar to the TRC.

Just as people's tribunals often mirror criminal tribunals "with a real judicial procedure, real judges, real lawyers, and real witnesses," ${ }^{, 9}$ Speak Out replicated several TRC practices, procedures, and symbols. While Archbishop Desmond Tutu headed the TRC, his successor, Archbishop Njongonkulu Ndungane, nominally headed Speak Out. A natural choice in several respects, Ndungane, a former political prisoner on Robben Island, spoke out against poverty at his public ordination in 1996, and continued calling for action on poverty (Anglican Communion News Service 1997; Pretoria News 1998). Like the TRC, Speak Out collected statements (called written submissions); most significantly, it conceptualized the project of speaking out around the practice of victim hearings, the TRC's most public and dramatic face.

In each region, "commissioners" (i.e., Archbishop Ndungane, SAHRC or CGE commissioners, and persons from SANGOCO or one of its affiliates) presided over the hearings. The hearing's material space looked much like a TRC hearing: rows of seats for the public and deponents; a table where these commissioners sat facing the audience, with a large banner behind them; and deponents spoke into microphones in their chosen language, sometimes donning headphones to listen to simultaneous translations. Hearing procedures were also similar to the TRC. They included formal openings and in some cases a prayer. Deponents gave testimonies, and they were sometimes hurried along by the commissioners who asked follow-up questions.

Speak Out held ten public hearings across South Africa's nine regions over just more than three and a half months in 1998-the first hearing was on March 31 and the last on 
June 19 (SANGOCO 2000b, 1). As each hearing took three or more days in different towns or localities, it would be truer to say there were thirty-one separate hearings. According to Speak Out, "Nearly 600 people made oral submissions and over 10,000 people participated in the process either by making written submissions, attending the hearings or mobilising others to participate" (SANGOCO 2000b, 1). Submissions alone, both written and oral, including a number from callers to a toll-free telephone line, were estimated to be in the thousands. While Speak Out concedes that these figures represent a "miniscule proportion of the poor of the country" (SANGOCO 2000a, 8), they are a considerable achievement over just three months. In comparison, the TRC - with vastly greater resources - collected around twenty-two thousand "victim" statements over some two years, while just over two thousand deponents spoke at its public hearings; additionally the TRC received perhaps a few hundred submissions from political parties, institutions, civil society organizations, and individuals.

The profiles of Speak Out participants varied. In Johannesburg, NGOs provided a large proportion of submissions; in other cities and rural towns, the poor tended to speak. Many were themselves members of community organizations, and they sometimes spoke on behalf of their communities. Speak Out notes that "many had heard of Speak Out on Poverty via community organisations and NGOs," and "had often been assisted by them to attend" (SANGOCO 2000a, 4). This is in contrast to the TRC, in which the majority were not, as is sometimes assumed, political activists, but civilians caught up in violence either as occasional participants, or bystanders caught in crossfire (Fullard and Rousseau 2008; Reynolds 2013). Speak Out notes of its own deponents that their stories, "and the fact that they reached the hearings, suggest that they were more resourceful, and perhaps slightly more advantaged than the average poor person" (SANGOCO 2000a, 8). Speak Out also notes that those who were employed, as well as many active work-seekers, were underrepresented because the hearings took place over weekdays and during work hours (13). This was true of most TRC deponents, too. Similarly, both institutions paid attention to locality, with hearings reaching into rural as well as urban spaces, and those testifying crossed demographic boundaries of gender, generation, and race.

Media coverage of Speak Out, however, was minimal, which was in sharp contrast to the TRC's massive media presence in South Africa and abroad. It may be that in choosing to replicate certain aspects of the TRC, Speak Out ironically became indistinguishable from TRC victims. Instead of resonating off the TRC, it seemed to harmonize with it. Thus, in using the TRC's hearing template, instead of being heard as witnesses to structural violence, deponents slipped into a generic category of suffering.

After the hearings concluded, Speak Out produced two reports, and their nature and style differed substantially from the TRC's reports. Although there is considerable variation in tone, style, and weight of truth commission reports (Fullard and Rousseau 2008, 233-35), they are regarded as a central aspect of their work. The TRC produced a seven-volume report (see Truth and Reconciliation Commission 1998, 2003). Intended as authoritative and comprehensive, it is still regarded as a less noteworthy aspect of the TRC (Bundy 2000; Cherry, Daniel, and Fullard 2002; Fullard and Rousseau 2008; Mamdani 2002; Posel 2002).

In contrast, Speak Out pursued a different strategy. Unlike the weighty TRC volumes, their two reports, The People's Voice (SANGOCO 2000a) and Poverty and Human Rights (SANGOCO 2000b) _ just soft-cover publications_-are a modest 64 and 106 pages, respectively. There is significant overlap between the two: the latter provides a summary of findings, and the former-the more "popular version"-is aimed at and distributed to those 
who had spoken out. Organizers crafted the reports as lobbying and campaign tools: one target was the TRC itself, just months away from publishing its first five volumes. According to the then SANGOCO director, a copy of these reports would be presented to the TRC because, were it to omit "violations of socio-economic rights, it would be ... undermining [its] own mandate" (Sunday Independent 1998, 1).

Organizers approached recommendations-a core responsibility of transitional justice mechanisms and often, as with the TRC, a weak and neglected area of study (Skaar, Malca, and Eide 2015, 50) —in a similar manner. Although the findings report includes a modest list of recommendations (SANGOCO 2000a, 84-85; 2000b, 41-48), it focused on popularizing a War on Poverty Declaration. Speak Out described this declaration, adopted in August 1997 at the War on Poverty Forum, as "a poverty commitment which people will be asked to sign and implement over the next year" (2000 a, 4), as part of making poverty "the national priority" (8).

\section{Speak Out Hearings: Discursive Space and Subjectivities}

In discussing Speak Out in relation to the TRC, rather than signaling a set of comparisons, my interest lies in the ways in which Speak Out spoke from within and against the noise of the TRC, and to what effect. Through its attention to poverty and inequality, and their associated deep histories of structural violence, Speak Out emphatically drew a distinction between itself and the TRC. Archbishop Ndungane stated bluntly: "I want to make it clear, because sometimes people get confused, we are not the TRC." 10 I read in this emphatic insistence an attempt to redirect attention from the TRC's individuated political violence to ongoing legacies of poverty and inequality.

There is considerable debate as to whether the failure to look at the wider legacies of colonialism and apartheid, in particular poverty and inequality, lay within the TRC's mandate, or its interpretation. This debate is part of a critique of transitional justice and its assumed (neo)liberal political projects (Bowsher 2018; Grandin and Klubock 2007; Neocosmos 2011; Wilson 2001). It is also a debate within rights circles (Arbour 2007; Gready and Robins 2014; Lambourne 2009; Laplante 2008; Miller 2008; Sharp 2014). Space here does not permit a more extended discussion of this well-rehearsed debate (Asmal and Roberts 1999; Mamdani 1996; Sharp 2014; Truth and Reconciliation Commission 1998).

Suffice it to say that SANGOCO cosigned a substantial submission to the TRC in March 1997, which argued for a wider interpretation of its mandate (Community Law Centre et al. 1997); many affiliates of SANGOCO had themselves lobbied—and had been involved in lobbying for - the TRC. After a lengthy internal debate (Truth and Reconciliation Commission Volume 1 1998, 60-65), the TRC decided such an interpretation exceeded its mandate. It argued that it lacked resources, and there were other institutions (such as the Land Commission and the Reconstruction and Development Programme) that were better placed to tackle apartheid's socio-economic legacies. The TRC's mandate covered only the years of armed conflict (1960-1994), not the apartheid period (1948-1994), suggesting that Parliament had intended the TRC to confine its attention to violations committed in the struggle to defend or end apartheid: torture, abduction, killing, and severe ill-treatment (60-65).

However, the TRC confirmed apartheid as a crime against humanity (Truth and Reconciliation Commission Volume 1 1998, 94-102) and organized "sector hearings" aimed at holding those institutions responsible for creating or sustaining an enabling environment for human rights abuse to account (Truth and Reconciliation Commission Volume 4 1998). Of specific interest, a business sector hearing, which took place just four months before 
Speak Out hearings began, led the TRC to find that apartheid benefited capitalism (58; Nattrass 1999).

Many clearly regarded these efforts as insufficient. A news report cited Jacqui Boulle, SANGOCO's program director, as describing Speak Out as "an alternative platform" arising from the TRC's failure "to give a substantive focus to violations of socio-economic rights" (Sunday Independent 1998, 1). A Speak Out report opens with these words: "Through the Truth and Reconciliation Commission we've heard about the political and civil rights violations under apartheid. But what about violations of social and economic rights?" (SANGOCO 2000b, 1). Archbishop Ndungane asserted at the hearing in rural Nquthu: "Poverty is the greatest legacy of apartheid." 11 In opening the Western Cape hearing in Khayelitsha, a massive apartheid-era township in which most residents continue to live in shacks, and only sixteen kilometers from Cape Town's International Airport, commissioner Moulana Faried Esack noted that as "people talk about 'the new South Africa' etc [sic], underneath, there is another reality. The reality that the poor [are] becoming poorer and the rich richer." 12

In insisting on a more substantial engagement with socio-economic legacies, for the short period of its public existence, Speak Out challenged notions of reconciliation and nation-building that did not have inequity and poverty at their center. The effect of this was to question whether the apartheid past had ended, and that a "never again" ethos to human rights abuse was insufficient without attention to apartheid's structural and everyday harms. In important respects, then, Speak Out can be read as a challenge to the discursive frameworks through which the TRC made the past intelligible, in an effort to shift public discourse from reconciliation to poverty and inequality.

Nevertheless, certain strategic choices had unforeseen consequences with far-reaching discursive effects. These choices undermined some of Speak Out's intent and produced inaudibility. First, as suggested above, in closely replicating TRC's practices, Speak Out may have been absorbed into a more generic time of testifying. Second, Speak Out focused on the present (and desired future). The People's Voice notes that Speak Out "concentrates on current problems rather than those of the past" (SANGOCO 2000a, 1). Thus, although it recognized that "many stories made it clear that current problems were a result of past discrimination and disadvantage, and that there is still a long way to go before apartheid's distortions are straightened out" (1), like the TRC, Speak Out tended to treat apartheid as a backdrop rather than as its central focus. Transcripts suggest Speak Out's commissioners rarely mentioned apartheid's everyday harms in opening comments, unless (as in the earlier quote from Archbishop Ndungane) as "legacy."

The focus on the present and future responds to an important criticism that the TRC was backward-looking and failed to connect with pressing issues of transition, including violence (Balint, Laslett, and Macdonald 2017; Gready 2011; Kesselring 2017; Simpson 2000, 2002). One of Mahmood Mamdani's most compelling criticisms of the TRC is that its narrow definition of political violence and accompanying perpetrator-victim discourse allowed beneficiaries (i.e., white South Africans) to steal away like thieves in the night, only to slip in among the throng of victims, claiming in the light of day they had been ignorant of depredations committed by apartheid security forces (Mamdani 1998, 38-40). In not focusing more on apartheid, Speak Out similarly sidestepped white privilege.

If Speak Out rarely addressed either beneficiaries or perpetrators of economic exploitation, deponents-similarly to their TRC counterparts—sometimes did, contesting or exceeding the boundaries intended by organizers. Thus, Jan Rooi told the Northern Cape hearing: "We were broken down. We suffered injustices.... Today we are bitter when we think back on those days. I could have been a strong and rich stock farmer today, but 
instead I am filled with hate" (SANGOCO 2000a, 9). Although encouraged to speak of their present problems, deponents sometimes testified to how apartheid's past continued in the present. Hans Monyi, of Mmabatho, told a North West hearing that he had been "beaten up and called a Kaffir by a white family who stole six cows" (11), while Simon Msiza said, "Last year whites were sent to destroy our property. They came with a gun. He looked at me. He shot the tree behind me. I said: 'What are you doing?' He said: 'I am only shooting at baboons" (14). Today, nearly twenty-five years after the formal ending of apartheid, racist statements such as these continue to surface regularly in public life.

A second strategic choice was to choose the Constitution's Bill of Rights as the discursive register of hearings and reports. Speak Out organized hearings thematically around those socio-economic rights inscribed in the Bill of Rights. More than the TRC, South Africa's Constitution, lauded as a progressive constitution, drew a line between the apartheid past and a "new" South Africa. In order to make it "a living document," government departments, post offices, religious institutions, and NGOs distributed an abridged paperback pocket version, published in all eleven official languages. Speak Out extended this project, aiming both to educate those previously regarded as noncitizens about their rights and to instate these rights as part of a popular consciousness and organization. Thus, each Speak Out hearing (with three exceptions) focused on a theme associated with a specific socio-economic right. These themes included land and development in the rural Northern Province (later renamed Limpopo); Social Security in the Eastern Cape (the Northern Province and Eastern Cape are South Africa's two poorest provinces); the economy in Gauteng, South Africa's economic powerhouse; housing and urban development in Cape Town, South Africa's second largest city; education in the Free State; and health care in KwaZulu Natal.

The Bill of Rights also structured reports-following frequent observations by many deponents and the organizers themselves that people lacked knowledge of their rights—on how to access government benefits and services. For instance, in Grahamstown, a university town in Eastern Cape that nonetheless has high levels of unemployment and low literacy rates, hundreds of poor, elderly people flocked to the Social Security hearing hoping that the gathering would facilitate access to pensions (SANGOCO 2000a, 9). The reports list each right and discuss the government's progress in promoting that right. Alongside this is each right's counter-posed history of violations during the apartheid era. This includes its "impact on the poor," including "obstacles to community access" and people's "understanding of their rights, and how they can enforce them" (SANGOCO 2000b, 3). Both Speak Out reports are framed by "(allowing) the poor themselves to say how they experience it," (SANGOCO 2000a, 8) and with the suggestion that "the testimony and submissions presented at the hearings by poor people and the organisations that work closely with them ... [provided] a basis for... reflections and conclusions" (SANGOCO 2000b, 3). Here again, the reports act more as organizational tools than as sets of findings and authoritative pronouncements, which tend to characterize commission and criminal tribunal reports.

While people's tribunals have chosen a dominantly legal frame, and truth commissions tend to be framed by law owing to their official status, Speak Out's positioning in relation to law was somewhat more ambivalent. Its mobilization of community organizations, its reports, and its commitment to a national campaign rather than formal recommendations tend to suggest a more activist orientation, and one demanding accountability. A Speak Out report notes: "By recognising these rights, the eradication of poverty becomes not merely a policy choice for the State, but a legally binding responsibility for which it is accountable" (SANGOCO 2000b, 2). Nonetheless, despite a more assertive discourse of mobilizing, rights, and accountability, by choosing the Bill of Rights as a framing 
device for its hearings, submissions, and reports, Speak Out returned to the law and the state.

Another strategic choice concerned the testifying subject. Against violated individuated bodies associated with the TRC, Speak Out instated the collective figure of "the poor." Here, following Prete and Cournil's notion of "righteous witnesses" (this issue), the poor claimed a subject position in the new nation by speaking out about their daily experience of poverty and inequality. In doing so, they challenged what critics saw as the construction of victimhood by the TRC, placing the agency of the poor in place of the victim. Many TRC commissioners themselves struggled with the term victim, but retained it because it was the term used in the mandate, and because the estimated twenty-five thousand persons killed during the mandate period could not be described as survivors. Later scholarship complicates the TRC's victim-subject by suggesting that claiming victimhood may be agentive rather than passive (Cole 2010; Ross 2003; Sanders 2007). Kesselring's (2017) study on the Khulumani Support Group discusses victimhood in the afterlife of the TRC.

While TRC banners proclaimed "Truth, the Road to Reconciliation" and "Healing is Revealing," banners at poverty hearings simply replicated its name; that is, "Speak Out on Poverty," as did the ubiquitous uniform of the antiapartheid struggle: the T-shirt. Similarly, although hearings seemed to follow the same procedures of welcome, prayer, and testimony followed by questions, Speak Out commissioners actively invoked agency. For example, commissioners asked the following kinds of questions: "What are the solutions?"; "What do you suggest?"; "What does empower mean?"; "Does the larger community help?", What are you doing about that?"; "What now? What is the next step?"13 Designed to represent the poor as agentive, this line of questioning can be understood as mobilizing not the resistance figure of the struggle era but the rights-bearing citizen of the "new" South Africa. In many cases, deponents themselves would outline their or their community's endeavors to overcome poverty.

It is possible to view these discursive struggles as struggles over who apartheid's subaltern subject would become in a post-democratic South Africa. While the African National Congress held a notion of itself as a liberation movement, this existed in some tension with its status as ruling party; while the liberation struggle's subject was a resistance figure, governance required "responsible" citizens (Chipkin 2003; Hart 2008; James 2013). There were some signs already that government sought a citizen who would wait patiently for it to deliver on its promises. Against this, Speak Out's rights-based citizens, able and already engaged in their own emancipation, thus contested not only the TRC's victimsubject but also the passive citizen-subject of the democratic order. Ironically, the South African government's 2012 National Democratic Plan decried a culture of dependence, and called for an active citizenry (National Planning Commission n.d.). In its efforts to produce the rights-bearing citizen, here too one could conclude that, as with truth commissions, subjectivities were narrated through law and remained within, rather than outside, sovereignty's purview.

Despite the extent to which deponents spoke to the ways in which they sought to change their lives - testifying to the importance of organization, and how they had resisted even heart-stopping obstacles (not least, the frequent crushing indifference of both apartheid and new order civil servants) - escaping the binds of victimhood was not easy. This created a tension between desires to refuse victimhood and odds so overwhelming that it was hard to deny some form of victimhood, again folding Speak Out into the TRC's discursive space, thus disabling its capacity to be heard above the noise of the TRC. In many instances, appeals for help, sometimes even an assertion of victimhood, accompanied testimonies. In the attempts to escape the binds of victimhood, commissioners and the reports placed 
considerable emphasis on "the ingenuity and creativity of people who survive against all odds" (SANGOCO 2000a, 1), and praised "inspiring stories of how people-mainly women-had come together in groups to engage in income-earning and other activities" (4). Conversely, TRC commissioners frequently praised victims or their families for bravery and contributing to the struggle for freedom. At the same time, as the framing comments to Speak Out hearings and the reports made clear, Speak Out largely addressed the government and the ruling party, which had campaigned on an electoral promise of "a better life for all." Comments from commissioners that Speak Out would draw the government's attention to concerns and problems raised by deponents laced hearings, as did promises that "the people's voice" would "be heard." Thus, Volume 1 notes:

Those who organised the hearings hoped that they would provide the opportunity to hear what solutions poor people had to offer.... (Despite) concrete evidence of ... survival strategies ... they were clear that these solutions would not be successful without some outside assistance.... Resourcefulness [is] not enough.... In a situation of extreme poverty, it is difficult, if not impossible, for people to pull themselves up by their bootstraps without an enabling environment. (SANGOCO 2000a, 4)

This echoes Martin Luther King Jr.'s 1967 much-cited comment: "It's a cruel jest to say to a bootless man that he ought to lift himself by his own bootstraps." More problematic, it assumed the people's voice required an intermediary. The production of this intermediary was unintended. Given the government's membership in the War on Poverty Forum, organizers had anticipated it would participate in hearings. A Speak Out organizer indicated anxiety on the part of government, the ruling party, and its alliance partners, possibly anticipating criticism in the context of upcoming parliamentary elections. ${ }^{14}$ Nonetheless, however framed, such comments tended to position the post-democratic government in the driver's seat. It is perhaps useful to consider how a discourse of rights-bearing citizens articulates with one of thwarted self-help and empowerment, requiring government agency to put things right. Ironically, the latter inheres precisely in the tension between devastating poverty and the desire to assert agency.

Here I am reminded of how a discourse of vulnerability or special needs works in relation to the marked categories of women, children, and disabled persons in South Africa. ${ }^{15}$ South Africa does not have, for example, a Ministry of Gender or a Ministry of Equity, but has a Ministry of Women, Children and People with Disabilities; in other words, replicating a discourse of unmarked male citizens and vulnerable others needing protection. With regard to Speak Out, the marked others who require assistance are none other than apartheid's poor, racialized subjects who constitute an overwhelming majority of South Africa population. To replicate such a discourse post-apartheid is to risk being mired in a colonial and apartheid logic.

In extending this argument, I note how a discourse on resourcefulness and self-help as a route to empowerment and communities of solidarity is entangled with a discourse on selfreliance. Such discourses have an emancipatory iteration, both in Black Consciousness' texts and other radical thought. However, Janeke Thumbran (2017) notes that a discourse of self-reliance is lodged in apartheid, while iterations of self-reliance and self-help inhere in neoliberalism (Amable 2011). By situating self-reliance within apartheid's discourse of separate development, and thus an iteration of long histories of trusteeship in colonial South Africa, Thumbran cautions those who underwrite empowerment projects through the discourse of self-help or self-reliance. Just as the apartheid government proclaimed 
the homelands as the site of production of "self-reliant black subjects," to proclaim that people and communities merely require assistance and support is perhaps, in hindsight, unintentionally to remain within rather than to break apart apartheid's logics. A further effect is once again that white privilege was occluded.

\section{Concluding Comments}

In concluding, to return to the distinctions between truth commissions and people's tribunals - one track of this article-Speak Out provides an example of an initiative that was neither a commission nor a people's tribunal, yet shared features of both. Its hearings and practices replicated the TRC's in important respects, yet it reflected something of the oppositional stance and intent of peoples' tribunals. Although existing in a time of transition, it focused on forms of violence that continued into the "new" South Africa and enjoyed impunity. Then, too, although initiated by community activists, the CGE's and SAHRC's involvement meant Speak Out spoke from both "inside" and "outside" the state. Thus, if people's tribunals position themselves "outside the formal framework of the state and international organizations" (Prete and Cournil this issue), then Speak Out, was at the same time both inside and outside the state.

In wearing both commission's and people's tribunal's accoutrements and intentions, Speak Out seemed more directed toward activism, and sometimes even described itself as a campaign. Yet such activism was moderated, or perhaps redirected, toward seeking forms of partnership with the South African government. This occurred at a moment in which the government's own commitments (and, by extension, the African National Congress as the ruling party) to socio-economic transformation were ambiguous: a macro-economic policy adopted without consultation and, conversely, its War on Poverty Forum. In sum, examining Speak Out questions assumed distinctions among truth commissions, associated transitional justice initiatives, and people's tribunals. This suggests that rather than making assumptions based on their respective fields, it is more productive to think of them more contingently. This would mean always to consider the questions of subjectivities and political possibilities afresh within the time-space in which they operate, not from the beginning of particular debates that frame the scholarship on truth commissions and people's tribunals. To do so may animate a more nuanced understanding and scholarship of such initiatives.

With regard to Speak Out's discursive space and subjectivities, the second track of this article suggests that several strategic choices by organizers had unexpected outcomes, such as unintentionally aiding inaudibility and constraining Speak Out's transformative ethos. In choosing to replicate many of the TRC's practices, it is possible that Speak Out became subsumed in the noise of the TRC. In seeking to focus on the future rather than the structural and everyday violence of apartheid, Speak Out once more let beneficiaries off the hook by deploying the Constitution's Bill of Rights as an organizing framework, which discursively returned Speak Out to the modalities of the nation and the state. The associated production of an active and rights-bearing citizen who could escape victimhood foundered on the sheer extent of apartheid's violence, poverty, and inequality, leaving in its place a thwarted discourse of self-help and self-reliance, and a subject whose empowerment was tethered to the agency of the government.

At the same time, I am somewhat dissatisfied with this reading for at least three reasons. First, I have read Speak Out's discursive space "from above" and have overemphasized the organizers' role and overgeneralized across both structure and hearings. My reading provides no insight into particular regions or hearings, or unexpected outcomes and contestations within Speak Out. As with assessments of the TRC, this reading tends to reduce hearings to a master discourse, occluding the plurality of voices, both Speak 
Out's commissioners and deponents. Such assessments from above reproduce the same arguments and positions that characterize much of the TRC's scholarship, and consign Speak Out, like the TRC, to rather predictable judgments. This is not what I intend, but to do otherwise requires further research.

Second, despite the impressive number of public hearings and the materiality of witnesses speaking into microphones while others listened to simultaneous translations through earphones, Speak Out seemed inaudible to a wider audience and received little attention. Unlike the revolving door of scholars and doctoral students tramping through the TRC during its work and in its aftermath, Speak Out received little research attention. That the perceived failure to confront the full spectrum of apartheid violence enjoys wide scholarly currency, and the failure to address legacies of poverty and structural violence is regarded as the transition's key fault line, only serves to underscore this scholarly neglect. To provide critical assessments in such a context would seem to be adding a further layer to the crushing silence that surrounds Speak Out. Then, too, assessing the public impact of Speak Out poses a question: Which public might one be referring to? It is possible that while seemingly inaudible in the media and corridors of power, Speak Out was perfectly audible within communities and NGOs, and that the hearings shaped subsequent politics and initiatives. This also requires further research and thought.

Finally, these were early days in the post-apartheid era. Speak Out represented varying ideological strands and histories, and existed between a moment of hope and disappointment. This is most evident in the tension between its attempt to speak to and partner with the government in making the War on Poverty the national priority, and the absence of the government, the ruling party, and alliance partners at hearings. Nonetheless, Speak Out articulates some of the first organized public expressions of disappointment about transformation. ${ }^{16}$ Moulana Faried Esack opened the hearing in the rural town of Ceres, Western Cape, with these words: "We have a black government, a good president, a constitution, and many promises. But the experience of suffering and oppression is the experience of the majority of the people." ${ }^{17}$ In Umtata, in the Eastern Cape, Reverend Alfred Myeko opened with a prayer in which he proclaimed:

Man's instinct is to live, but that life must be abundant. Basic needs must be met, otherwise there is a lop-sidedness. You are here to be a voice for the voiceless. We are going to pray to the rich landlords of Israel, and the God of the poor landless of Israel. ${ }^{18}$

Rather than seeing institutions such as the TRC and Speak Out as bounded, and issuing judgments locking them in the iron grip of certitude, I understand these as maneuvers on the terrain of a transitional time that was uncertain and contested. Here, too, more careful and nuanced histories of the transition are sorely needed. Nonetheless, however flawed, both the TRC and Speak Out provided a reading of that time, as well as the horizons of an apartheid past and its imprint on lives and bodies, and imagined and desired futures.

\section{Notes}

Many thanks to the anonymous reviewers for their careful reading and responses.

1. World Bank. "GINI Index World Bank Estimate." https://data.worldbank.org/indicator/ SI.POV.GINI?locations=ZA.

2. Statement of Deputy President Thabo Mbeki at the opening of the debate in the National Assembly, "Reconciliation and Nation Building," National Assembly Cape Town, 
May 29, 1998, https://www.sahistory.org.za/archive/statement-deputy-presidentthabo-mbeki-opening-debate-national-assembly-reconciliation-and-n.

3. Pardis Shafafi, "Peoples' Tribunals: Perceived Perils and Merits" (unpublished manuscript, December 18, 2018, 10), Microsoft Word. Cited with permission of the author.

4. In the apartheid era, many community organizations, NGOs, and social movements had strong links to antiapartheid political movements (Habib and Taylor 1999). References to civil society, unless otherwise specified, refer to such groupings.

5. Shafafi, "Peoples' Tribunals," 8.

6. Speak Out solicited a number of submissions from experts. Additionally, it received personal written accounts, which it refers to as submissions.

7. This description is from an earlier version of SANGOCO's website (http://www. sangoco.org.za, accessed on October 24, 2014), which has now been revised and updated.

8. South African Government, Constitution of the Republic of South Africa Act 108 of 1996, http://www.justice.gov.za/legislation/constitution/SAConstitution-web-eng-09. pdf.

9. Excerpts from the speech of Marie-Monique Robin, a key organizer, at the International Monsanto Tribunal press conference, December 3, 2015 (quoted in Cournil and Prete this issue).

10. Minutes, KwaZulu Natal, May 11-16, 1998, 62.

11. Minutes, KwaZulu Natal, May 11-16, 1998, 81.

12. Minutes, Western Province, June 1-4, 1998, 22.

13. These particular examples have been taken from the Mpumulanga hearings, but are replicated across other hearings too. Minutes, Mpumulanga, April 27-28, 1998, 6-13.

14. Personal communication with a campaign coordinator. With regard to alliance partners, the African National Congress, the Congress of South African Trade Unions, and the South African Communist Party entered into a strategic political alliance in 1990, and continue to be part of this tripartite alliance.

15. I should point out that not providing a gendered account of Speak Out is a significant shortcoming of this article, but that requires a more careful study of hearing records; this is complicated by the absence of professional transcription across all the hearings.

16. Another initiative emerging at the same time was the Treatment Action Campaign, which, also drawing on the notion of speaking out and the Constitution, mobilized thousands behind the demand for the right to antiretroviral drugs.

17. Minutes, Western Cape, June 1-4, 1998, 55.

18. Minutes, Eastern Cape Hearing, May 18-23, 1998, 5.

\section{References Cited}

Amable, Bruno. 2011. "Morals and Politics in the Ideology of Liberalism." Socio- Economic Review 9 (1):3-30.

Anglican Communion News Service. 1997. "South African Primate to Hold Summit on Poverty," September 3, 1997, https://www.anglicannews.org/news/1997/09/southafrican-primate-to-hold-summit-on-poverty.aspx

Arbour, Louise. 2007. "Economic and Social Justice for Societies in Transition." New York University Journal of International Law and Politics 40 (1): 1-27. 
Asmal, Kader, and Ronald S. Roberts. 1999. Reconciliation Through Truth: A Reckoning of Apartheid's Criminal Governance, 2nd ed. Cape Town: David Philip Publishers.

Balint, Jennifer, Kristian Lasslett, and Kate Macdonald. 2017. " 'Post-Conflict' Reconstruction: The Crimes of the Powerful and Transitional Justice." State Crime Journal 6 (1): 4-12.

Bond, Patrick. 2003. Against Global Apartheid: South Africa Meets the World Bank, IMF and International Finance. London: Zed Press.

Boraine, Alexander and eds. 1995. The Healing of a Nation? Cape Town: Justice in Transition.

Bowsher, Josh. 2018. “'Omnus et Singulatim': Establishing the Relationship Between Transitional Justice and Neoliberalism.” Law and Critique 29 (1): 83-106.

Bundy, Colin. 2000. "The Beast of the Past: History and the TRC." In After the TRC: Reflections on Truth and Reconciliation in South Africa, edited by Wilmot G. James and Linda Van de Vijver, 9-11. Cape Town: David Philip.

Cherry, Janet, John Daniel, and Madeleine Fullard. 2002. In Commissioning the Past: Understanding South Africa's Truth and Reconciliation Commission, edited by Deborah Posel and Graeme Simpson, 17-36. Johannesburg: Witwatersrand University Press.

Chipkin, Ivor. 2003. "'Functional' and 'Dysfunctional' Communities: The Making of National Citizens.” Journal of Southern African Studies 29 (1): 63-82.

Community Law Centre (UWC), Development Action Group, Legal Resources Centre. 1997. "Submission to the Truth and Reconciliation Commission Concerning the Relevance of Social, Economic and Cultural Rights to the Commission's Mandate," March 18, 1997, http://www.justice.gov.za/trc/hrvtrans/submit/esc6.htm.

Cole, Catherine M. 2010. Performing South Africa's Truth Commission: Stages of Transition. Bloomington. Indiana University Press.

Fullard, Madeleine, and Nicky Rousseau. 2008. "Uncertain Borders: The TRC and the (Un)making of Public Myths.” Kronos 34 (1): 215-39.

Grandin, Greg, and Thomas M. Klubock. 2007. "Editors' Introduction.” Radical History Review Volume 2007 (97):1-10.

Gready, Paul. 2011. The Era of Transitional Justice: The Aftermath of the Truth and Reconciliation Commission in South Africa and Beyond. Oxford: Routledge.

and Simon Robins. 2014. "From Transitional to Transformative Justice: A New Agenda for Practice." International Journal of Transitional Justice 8 (3): 339-61.

Habib, Adam and Rupert Taylor. 1999. "South Africa: Anti-Apartheid NGOs in Transition." VOLUNTAS: International Journal of Voluntary and Nonprofit Organizations 10 (1): 7382.

Hamber, Brendon, Thloki Mofokeng, and Graeme Simpson.1997. "Evaluating the Role and Function of Civil Society in a Changing South Africa: The Truth and Reconciliation Commission as a Case Study." Paper presented at the Role of Southern Organisations in the Promotion of Peace Seminar, DHR Seminar, Catholic Institute for International Relations, London, November 10. http://www.csvr.org.za/publications/latest-publications/ 1715-evaluating-the-role-and-function-of-civil-society-in-a-changing-south-africa-thetruth-and-reconciliation-commission-as-a-case-study.

Hart, Gillian. 2008. "The Provocations of Neo-Liberalism: Contesting the Nation and Liberation After Apartheid." Antipode 40 (4):678-705.

James, Deborah. 2013. "Citizenship and Land in South Africa: From Rights to Responsibilities." Critique of Anthropology 33 (1): 26-46. 
Kesselring, Rita. 2017. Bodies of Truth: Law, Memory and Emancipation in Port-Apartheid South Africa. Stanford, CA: Stanford University Press.

Klinghoffer Arthur J., and Judith A. Klinghoffer. 2002. International Citizens Tribunals: Mobilizing Public Opinion to Advance Human Rights. New York: Palgrave.

Lambourne, Wendy. 2009. "Transitional Justice and Peacebuilding after Mass Violence." International Journal of Transitional Justice 3 (1): 28-48.

Laplante, Lisa L. 2008. "Transitional Justice and Peacebuilding: Diagnosing and Addressing the Socio-Economic Roots of Violence through a Human Rights Framework." International Journal of Transitional Justice 2:331-55.

Mamdani, Mahmood. 1996. "Reconciliation without Justice." Southern African Review of Books 8 (6): 3-5.

1998. “A Diminished Truth.” Siyaya, 3, Spring, 1998, 38-40.

2002. "Amnesty or Impunity? A Preliminary Critique of the Report of the Truth and Reconciliation Commission of South Africa." Diacritics 32 (3-4): 32-59.

Miller, Zinaida. 2008. "Effects of Invisibility: In Search of the 'Economic' in Transitional Justice.” International Journal of Transitional Justice 2 (3): 266-91.

National Planning Commission. N.d. National Development Plan 2030: Our Future-Make It Work. Republic of South Africa: National Planning Commission. https://www.poa.gov. $\mathrm{za} /$ news/Documents/NPC\%20National\%20Development\%20Plan\%20Vision\%2020 30\%20-lo-res.pdf.

Nattrass, Nicoli. 1999. "The Truth and Reconciliation Commission on Business and Apartheid: A Critical Evaluation." African Affairs 98 (392): 373-91.

Neocosmos, Michael. 2011. "Transition, Human Rights, Violence: Rethinking a Liberal Political Relationship in the African Neo-Colony." Interface 3 (2): 359-99.

Padayachee, Vishnu. 1998. "Progressive Academic Economists and the Challenge of Development in South Africa's Decade of Liberation. Review of African Political Economy 25 (77): 431-50.

Posel, Deborah. 2002. "The TRC Report: What Kind of History? What Kind of Truth?" In Commissioning the Past: Understanding South Africa's Truth and Reconciliation Commission, edited by Deborah Posel and Graeme Simpson, 147-72. Johannesburg: Witwatersrand University Press.

Pretoria News. 1998. "Archbishop Questions States 'Political Will' to Help the Poor," March 3:3.

Reynolds, Pamela. 2013. War in Worcester: Youth and the Apartheid State. New York: Fordham University Press.

Ross, Fiona. 2003. Bearing Witness: Women and the Truth and Reconciliation Commission in South Africa. London: Pluto Press.

Sanders, Mark. 2007. Ambiguities of Witnessing: Law and Literature in the Time of a Truth Commission. Stanford: Stanford University Press.

SANGOCO. 2000a. Speak Out on Poverty: The People's Voice. Braamfontein: SANGOCO. 2000b. Speak Out on Poverty: Poverty and Human Rights. Braamfontein: SANGOCO.

Sharp, Dustin N. 2014. "Economic Violence in the Practice of African Truth Commissions." In Justice and Economic Violence in Transition, edited by Dustin N. Sharp, 79-108. New York: Springer.

Simpson, Graeme. 2000. "Rebuilding Fractured Societies: Reconstruction, Reconciliation and the Changing Nature of Violence-Some Critical Insights from Post-Apartheid 
South Africa." Paper commissioned by the United Nations Development Programme (UNDP). http://csvr.org.za/docs/reconciliation/rebuildingfracturedsocieties.pdf.

. 2002. “Uncivil Society': Challenges for Reconciliation and Justice in South Africa after the Truth and Reconciliation Commission." Centre for the Study of Violence and Reconciliation, paper presented in Sweden. https://www.csvr.org.za/docs/ trc/uncivilsociety.pdf.

Skaar, Elin, Gianelli Malca, and Trine Eide. 2015. After Violence: Transitional Justice, Peace, and Democracy. Oxford: Routledge.

South African Government. Constitution of the Republic of South Africa, Act 108 of 1996, http://www.justice.gov.za/legislation/constitution/SAConstitution-web-eng-09.pdf.

The Star. 1997. "Organisations Draw Swords on All-Out War on Poverty," August 22:7.

Sunday Independent. 1998. "Poverty Report Fills in the Gaps Left by the TRC," July 19.

Terreblanche, Solomon. 2012. Lost in Transformation: South Africa's Search for a New Future Since 1986. Johannesburg: KMM Publishing Company.

Thumbran, Janeke. 2017. "Separate Development and Self-Reliance at the University of Pretoria." Kronos 43 (1): 114-25.

Truth and Reconciliation Commission. 1998. Truth and Reconciliation Commission of South Africa Report, Volume 1-5. Cape Town: Juta.

- 2003. Truth and Reconciliation Commission of South Africa Report, Volume 6-7. Cape Town: Juta.

United Nations Development Programme. 1994. Human Development Report 1994. New York: Oxford University Press. http://hdr.undp.org/sites/default/files/reports/255/hdr_ 1994_en_complete_nostats.pdf.

Wilson, Richard. 2001. The Politics of Truth and Reconciliation in South Africa: Legitimizing the Post-Apartheid State. Cambridge: Cambridge University Press.

World Bank. 2018, March. Overcoming Poverty and Inequality in South Africa: An Assessment of Drivers, Constraints and Opportunities. Washington, DC: International Bank for Reconstruction and Development/The World Bank. http://documents.worldbank.org/ curated/en/530481521735906534/pdf/124521-REV-OUO-South-Africa-Poverty-andInequality-Assessment-Report-2018-FINAL-WEB.pdf. 